\title{
A SEXUAL \\ ODYSSEY
}

From Forbidden Fruit

to Cybersex 


\section{A SEXUAL ODYSSEY \\ From Forbidden Fruit to Cybersex}

KENNETH MAXWELL 


\section{Library of Congress Cataloging in Publication Data}

Maxwell, Kenneth E., [DATE]

A sexual odyssey: from forbidden fruit to cybersex / Kenneth Maxwell.

p. $\mathrm{cm}$.

Includes bibliographical references and index.

ISBN 978-0-306-45405-9

ISBN 978-1-4899-3462-8 (eBook)

DOI 10.1007/978-1-4899-3462-8

1. Sex customs-History. 2. Sex role-History. 3. Computer sex. I. Title. HQ12.M378 1996

Additional material to this book can be downloaded from http://extras.springer.com

The publisher and author disclaim responsibility for any adverse effects or consequences from the misapplication or injudicious use of the information contained within this text. Never use any drugs, medical procedures, or medical products without the consultation and instruction of your physician. The publisher and author are not endorsing or promoting any products within the confines of this work.

ISBN 978-0-306-45405-9

(C) 1996 Kenneth Maxwell

Originally published by Plenum Publishing Corporation, New York in 1996 Softcover reprint of the hardcover 1st edition 1996

An Insight Book

10987654321

All rights reserved

No part of this book may be reproduced, stored in a retrieval system, or transmitted in any form or by any means, electronic, mechanical, photocopying, microfilming, recording, or otherwise, without written permission from the Publisher 


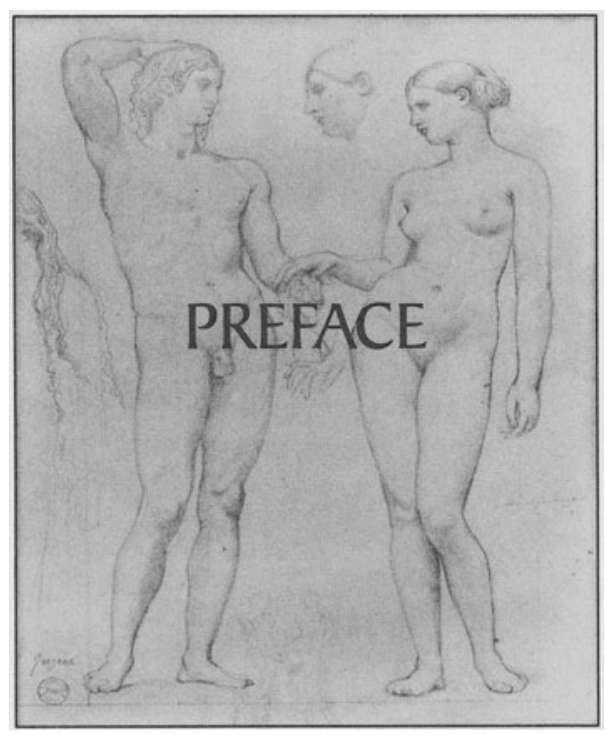

$S_{\text {ex is no longer simply the perennial target of moralists intent on }}$ taking the fun out of bedtimè sport. The problems and pleasures of sex have become serious studies of medical doctors, psychologists, psychiatrists, sex therapists, sociologists, sexologists, demographers, and teachers. To these are added the contributions of writers described as experts in a steady stream of essays on the art of love, dating from the works of Ovid in first century Rome to the present.

If sex has a future, it is rooted in the past-more than 3.5 billion years ago when young Mother Earth cradled a microscopic form of matter endowed with the miraculous qualities we call life. The first forms of life were invisible, even if there had been eyes to see them. As the evolutionary clock ticked away-ticks measured in millions of years-diverse forms managed to survive in the harsh and dangerous young world. These microscopic organisms, still hardly big enough to cast a shadow, made an astounding discovery that was to determine the state of the living world 


\section{vi A Sexual Odyssey}

forever. They found that sex, that is, the transfer of genetic material between consenting microbes, gave them a leg up on survival in an ever-changing hostile environment. Sex remained a dominant force through the millennia. How we manage sex in the future is destined to change our habits, social structure, and above all, the quality of life in astonishing ways. 


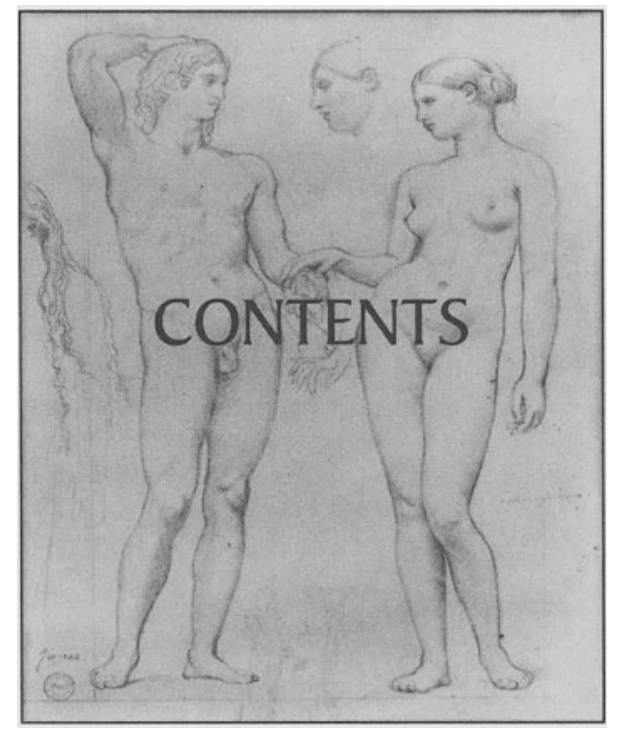

Introduction: The Brave New World of Sex .......... I

One The Naked Truth ........... 6

Two The Impossible Dream ....... 25

Three Joys "R" Us ............. 48

Four The Sex Wars ........... 56

Five $\quad$ Bed Roles .............. 80

Six The Masculine Mystique ...... 108

Seven Mating for Money .......... 127

Eight Same-Sex Sex ............. 148

Nine Making Babies ............ 165

Ten Tempest in a Test Tube ...... 195 
viii A Sexual Odyssey

Eleven The Copulation Explosion ...... 221

Twelve Cybersex.............. 250

Thirteen Future Sex ........... 270

Endnotes ............ 277

Index .............. 307 